\title{
The Relationship of Plasma Homocysteine Levels and the Methylenetetrahydrofolate Reductase C677T Gene Polymorphism to Ankylosing Spondylitis in a Chinese Population
}

\author{
Çinlilerde Plazma Homosistein Düzeyleri ve Metilentetrahidrofolat Redüktaz C677T \\ Gen Polimorfizminin Ankilozan Spondilit ile İlişkisi
}

Ni MAO, Jinwei CHEN, Wenfeng PENG, Lixiao CHEN, Xi XIE

Department of Rheumatology, The Second Xiangya Hospital of Central South University, Changsha, China

Objectives: The aim of this study was to investigate the relationship of both the plasma homocysteine (Hcy) level and N5,N10-methylenetetrahydrofolate reductase (MTFHR) gene polymorphism with ankylosing spondylitis (AS).

Patients and methods: Two hundred Chinese patients with AS and 120 healthy controls were included. The plasma Hcy level was examined by enzyme-linked immunosorbent assay (ELISA), while the MTHFR gene polymorphism was analyzed by the polymerase chain reaction $(P C R)$ and restriction fragment length polymorphism (RFLP).

Results: The two groups were examined according to age, and no statistically significant differences were found. The plasma Hcy level in the AS group was significantly higher than the control group ( $\mathrm{t}=24.402, \mathrm{p}=0.000)$. The ratio of the $\mathrm{T} / \mathrm{T}$ genotype mutation was different in the AS group and the control group (X2=9.874, $p=0.002)$ There was no marked difference in the frequencies of the MTHFR $\mathrm{C} / \mathrm{C}$, or $\mathrm{C} / \mathrm{T}$ genotype between the two groups. The plasma Hcy level of the T/T genotype was significantly higher than that of the $\mathrm{C} / \mathrm{T}$ or $\mathrm{C} / \mathrm{C}$ genotype in the AS group ( $q=6.496, p<0.01 ; q=12.088, p<0.01)$.

Conclusion: Our study result showed that the plasma Hcy levels were significantly increased in patients with AS, and the MTHFR T/T genotype mutation was an important influential mechanism which precipitated hyperhomocysteinemia and might be related to AS.

Key words: Ankylosing spondylitis; gene polymorphism; homocysteine; methylenetetrahydrofolate reductase.
Amaç: Bu çalışmada hem plazma homosistein düzeyi (Hcy) hem de N5,N10-metilentetrahidrofolat redüktaz (MTFHR) gen polimorfizminin ankilozan spondilit (AS) ile olan ilişkisi değerlendirildi.

Hastalar ve yöntemler: Çalışmaya 200 Çinli AS hastası ve 120 sağlıklı kontrol dahil edildi. Plazma Hcy düzeyi enzim bağlı immünosorbent assay (ELISA) ile muayene edildi, MTHFR gen polimorfizmi ise polimeraz zincir reaksiyonu (PCR) ve restriksiyon fragment uzunluk polimorfizmi (RFLP) ile analiz edildi.

Bulgular: İki grup da yaşa göre değerlendirildi ve gruplar arasında istatistiksel açıdan anlamlı bir farka rastlanmadı. AS grubunda plazma Hcy düzeyi, kontrol grubuna kıyasla anlamlı düzeyde daha yüksekti $(\mathrm{t}=24.402, \mathrm{p}=0.000)$. T/T genotip mutasyon oranı, AS grubunda ve kontrol grubunda farklıydı (X2=9.874, $\mathrm{p}=0.002)$. İki grup arasında MTHFR $\mathrm{C} / \mathrm{C}, \mathrm{C} / \mathrm{T}$ genotip sıklığı açısından belirgin bir fark yoktu. AS grubunda $T / T$ genotipin plazma Hcy düzeyi, $\mathrm{C} / \mathrm{T}$ veya $\mathrm{C} / \mathrm{C}$ genotipine kıyasla, anlamlı düzeyde daha yüksekti $(q=6.496$, $\mathrm{p}<0.01 ; \mathrm{q}=12.088, \mathrm{p}<0.01)$.

Sonuç: Çalışma bulguları, plazma Hcy düzeylerinin AS hastalarında anlamlı düzeyde arttığını ve hiperhomosisteinemiye zemin hazırlayan ve AS ile ilişkili olabilen MTHFR T/T genotip mutasyonu açısından önemli bir etki mekanizması olduğunu gösterdi.

Anahtar sözcükler: Ankilozan spondilit; gen polimorfizmi; homosistein; metilentetrahidrofolat redüktaz.

\footnotetext{
Received: February 9, 2012 Accepted: May 4, 2012

Correspondence: Jinwei Chen, M.D. Department of Rheumatology, The Second Xiangya Hospital of Central South University, Changsha, China. Tel: 0086+0731+85295285 e-mail: jinwei 73104@yahoo.com.cn 
Ankylosing spondylitis (AS) is a chronic, painful, degenerative inflammatory arthritis which primarily affects the spine and sacroiliac joints and which causes the eventual fusion of the spine. It is also an autoimmune disease with a probable genetic predisposition. Although its exact cause is unknown, we do know that genetics play a key role in AS. Most individuals who have this type of arthritis also have a gene that produces a "genetic marker", in this case a protein called human leukocyte antigen (HLA)-B27. Recent experimental data suggests that homocysteine (Hcy) may trigger autoimmune reactions through its ability to bind and structurally modify specific proteins, resulting in the formation of neoantigens that are potentially relevant either in the onset of specific autoimmune diseases or in the progression of the associated cardiovascular damage. ${ }^{[1]}$ The N5,N10 methylenetetrahydrofolate reductase (MTHFR) is a key enzyme in Hcy metabolism, A specific variant of the MTHFR gene replaces the nucleotide cytosine with the nucleotide thymine at position 677 in the MTHFR gene. This change in the MTHFR gene produces a form of MTHFR that has reduced activity at higher temperatures. People with the thermolabile form of the enzyme have increased levels of Hcy in their blood. We tested the plasma concentration and analyzed the polymorphysm of MTHFR in both the patients with AS and the healthy controls since it may offer new insights and strategies for the treatment of AS.

\section{PATIENTS AND METHODS}

\section{Subjects}

Two hundred patients with AS diagnosed according to the modified New York criteria of the American College of Rheumatology were recruited from the outpatients and inpatients of the Department of Rheumatology, in the Second Xiangya Hospital of Central South University in Hunan, China, and 120 healthy controls were enrolled in this study. All subjects were from the Han race of China. There were no significant differences in the ages of the participants in the two groups.

\section{Plasma homocysteine level}

Total Hcy concentrations were detected by an enzyme-linked immunosorbent assay (ELISA) kit (ADL Company, Bloomington, Minnesota, USA) and an absorbance microplate reader (Bio-Tek ELx-800, Winooski, Vermont, USA).

\section{Genotyping}

Genomic DNA was extracted manually via precipitation with trimethylammonium bromide salts from leukocytes contained in $450 \mathrm{ul}$ of venous blood using ethylenediaminetetraacetic acid (EDTA) as an anticoagulant. The DNA was then precipitated in $95 \%$ ethanol, dissolved in distilled water, and stored at $-20^{\circ} \mathrm{C}$ until analysis. The MTHFR C677T polymorphism was determined using the polymerase chain reactionrestriction fragment length polymorphism (PCRRFLP) assay. A 198bp fragment of the MTHFR gene was amplified from the genomic DNA with the primer pair P1 and P2. The prime sequences were: P1(sense): 5'-TGAAGGAGAAGGTGTCTGCGGGA-3' and P2(anti-sense):5'-AGGACGGTGCGGTGAGAGTG-3'. Per 6 ul PCR amplification was performed in a total volume of $20 \mathrm{ul}$. The amplification reaction was performed using the ABI PE-480 (Life Technologies Corporation, Carlsbad, California, America, USA). The PCR amplification consisted of an initial denaturation for five minutes at $94{ }^{\circ} \mathrm{C}$, followed by 35 cycles of denaturation at $94^{\circ} \mathrm{C}$ for 30 seconds (s), annealing at $56{ }^{\circ} \mathrm{C}$ for $30 \mathrm{~s}$ followed by extension at $72{ }^{\circ} \mathrm{C}$ for $30 \mathrm{~s}$. The terminal elongation was performed at $72{ }^{\circ} \mathrm{C}$ for five minutes. In an amplified 198bp fragment, the C677T polymorphism destroys a restriction enzyme cleavage site for Mbo I such that after digestion with this enzyme for 10 hours at $37^{\circ} \mathrm{C}$, the $677 \mathrm{C}$ allele can be detected by the presence of two fragments having lengths of 175bp and 23bp. The presence of the $677 \mathrm{~T}$ allele in the amplified segment, which remained uncut, and the presence of a heterozygous genotype result in the presence of all three bands. The DNA fragments generated after restriction enzyme digestion were separated in a $3 \%$ agarose gel. Restriction fragments were visualized after ethidium bromide staining of the agarose gel using an ultraviolet transilluminator.

\section{Statistical analysis}

Statistical evaluation was carried out with SPSS for Windows 13.0 version software program (SPSS Inc., Chicago, Illinois, USA). The total plasma Hcy levels in the AS group and the control group were compared with an independent sample t-test. The distribution of genotypes in the AS group was compared with the control group and statistically evaluated using a chisquare test.

The study conformed to the Helsinki declaration and was approved by the local ethics committee. 
Table 1. The C677T methylenetetrahydrofolate reductase genotype in the control group and ankylosing spondylitis group

\begin{tabular}{|c|c|c|c|c|c|c|}
\hline \multirow[t]{2}{*}{ Genotype } & \multicolumn{2}{|c|}{ Control $(n=120)$} & \multicolumn{2}{|c|}{ AS $(n=200)$} & \multirow[t]{2}{*}{$\mathrm{X}^{2}$} & \multirow[t]{2}{*}{$p$} \\
\hline & $\mathrm{n}$ & $\%$ & $\mathrm{n}$ & $\%$ & & \\
\hline 677CC & 72 & 60 & 100 & 33.3 & 3.017 & 0.082 \\
\hline 677CT & 42 & 35 & 66 & 44.5 & 0.714 & 0.714 \\
\hline $677 \mathrm{TT}$ & 6 & 5 & 34 & 22.2 & 9.874 & 0.002 \\
\hline
\end{tabular}

\section{RESULTS}

In the control group, six participants (5\%) were homozygous for the C677T mutation (TT genotype), 42 (35\%) were heterozygous (CT genotype), and 72 (60\%) were without the mutation (CC genotype). Among the AS group, the distribution between the TT, CT, and CC genotypes was 34 (17\%), 66 (33\%), and $100(50 \%)$, respectively. There was a difference in the total ratio of C677T MTHFR genotypes between the AS group and the control group $(\mathrm{X} 2=8.432,0.010<\mathrm{p}<0.025)$. There was also a difference in the ratio of $\mathrm{T} / \mathrm{T}$ genotype mutation between the AS group and the control group $(\mathrm{X} 2=9.874, \mathrm{p}=0.002)$, but no significant difference was seen in the frequencies of the MTHFR $\mathrm{C} / \mathrm{C}$ and $\mathrm{C} / \mathrm{T}$ genotype between the AS group and the control group (Table 1).

The plasma Hcy level was significantly higher in the AS group compared with the control group (median: $18.71 \pm 2.42 \mu \mathrm{mol} / \mathrm{l}$ versus $10.97 \pm 2.93 \mu \mathrm{mol} / \mathrm{l}$, $\min : 2.13 \mu \mathrm{mol} / \mathrm{l}$, $\max : 24.58 \mu \mathrm{mol} / \mathrm{l}, \mathrm{t}=24.402, \mathrm{p}=0.000$ ).
The plasma Hcy level of the $\mathrm{C} / \mathrm{C}, \mathrm{C} / \mathrm{T}$ and $\mathrm{T} / \mathrm{T}$ genotype in the AS group were significantly higher than what was found in the control group $(\mathrm{t}=17.402$, $\mathrm{p}=0.000 ; \mathrm{t}=16.166, \mathrm{p}=0.000 ; \mathrm{t}=10.686, \mathrm{p}=0.000$, respectively). A discrepancy also occurred in the plasma Hcy level of the C677T MTHFR genotypes between the AS group and the control group. $(\mathrm{F}=46.479, \mathrm{p}=0.000)$. In addition, the plasma Hcy level of the $\mathrm{T} / \mathrm{T}$ genotype was significantly higher than that of the $\mathrm{C} / \mathrm{T}$ or $\mathrm{C} / \mathrm{C}$ genotype in the AS group $(\mathrm{q}=6.496, \mathrm{p}<0.01 ; \mathrm{q}=12.088, \mathrm{p}<0.01$, respectively) (Tables 2 and 3).

\section{DISCUSSION}

Homocysteine is a chemical compound with the formula $\mathrm{HSCH} 2 \mathrm{CH} 2 \mathrm{CH}(\mathrm{NH} 2) \mathrm{CO} 2 \mathrm{H}$ and is a methylation of cells within the process of intermediate products. The change of plasma Hcy concentration can directly affect the genomic DNA methylation, which tends to repress gene expression while demethylation or hypomethylation activates the gene expression.

Table 2. The C677T methylenetetrahydrofolate reductase genotype plasma homocysteine level in the control group and ankylosing spondylitis group

\begin{tabular}{|c|c|c|c|c|c|c|}
\hline Genotype & $\frac{\text { Control }}{\mathrm{n}}$ & $\frac{\mathrm{n}=120}{\mathrm{Hcy}(\mu \mathrm{mol} / \mathrm{l})}$ & $\frac{\mathrm{AS}}{\mathrm{n}}$ & $\frac{\mathrm{n}=200}{\mathrm{Hcy}(\mu \mathrm{mol} / \mathrm{l})}$ & $\mathrm{t}$ & $p$ \\
\hline $677 \mathrm{CC}$ & 72 & $10.94 \pm 3.28$ & 100 & $18.31 \pm 1.94$ & 17.402 & 0.000 \\
\hline $677 \mathrm{CT}$ & 42 & $10.74 \pm 2.26$ & 66 & $17.80 \pm 2.18$ & 16.166 & 0.000 \\
\hline $677 \mathrm{TT}$ & 6 & $12.98 \pm 2.10$ & 34 & $21.70 \pm 1.80$ & 10.686 & 0.000 \\
\hline
\end{tabular}

Table 3. The C677T methylenetetrahydrofolate reductase genotype plasma homocysteine level in ankylosing spondylitis group

\begin{tabular}{lcccc}
\hline Genotype & $\mathrm{AS}$ & $\mathrm{n}=200$ & $\mathrm{q}$ & $p^{*}$ \\
\cline { 2 - 5 } & $\mathrm{n}$ & $\mathrm{Hcy}(\mu \mathrm{mol} / \mathrm{l})$ & & \\
\hline 677CC & 100 & $18.31 \pm 1.94$ & 12.088 & $<0.01$ \\
677CT & 66 & $17.80 \pm 2.18$ & 6.496 & $<0.01$ \\
677TT & 34 & $21.70 \pm 1.80$ & - & \\
\hline AS: Ankylosing spondylitis; Hcy: Homocysteine; ${ }^{*}$ Compared to TT as reference genotype. & \\
\hline
\end{tabular}


Research has revealed that hyperhomocycteine can lead to low genomic DNA methylation, which can be the source of many tumors and certain autoimmune diseases. ${ }^{[2,3]}$ Other research revealed that the plasma Hcy concentration of systemic lupus erythematosus (SLE), Behçet's disease (BD), and systemic sclerosis patients increased much more than normal. ${ }^{[4-6]}$ The relevance of the present study with regard to plasma Hcy concentration and AS is still in the start-up phase. Ankylosing spondylitis patients with hyperhomocysteine have been reported, ${ }^{[7-9]}$ and recent research has shown that the plasma Hcy level is not correlated with AS activation. ${ }^{[10,11]}$ However, the results of our study also showed that the plasma Hcy concentration in AS was significantly higher than in the controls. The exact mechanism of hyperhomocycteine in AS is currently not very clear, but study results show that hyperhomocycteine can enhance the activation of inflammatory cytokines and trigger the autoimmune mechanism. ${ }^{[1,12]}$ Homocysteine can also modify HLA antigens in the T cytotoxic lymphocytes, such as the HLA-B27 molecule and other surface molecules, resulting in functional abnormalities of $\mathrm{CD} 4+\mathrm{T}$ cells that leads to the occurrence of AS. ${ }^{[12]}$ Homocycteine is the metabolite of DNA methylation. The excessive accumulation of metabolic products will inhibit the DNA methylation process and reduce the level of DNA methylation, resulting in abnormal gene expression. Genes expressed differentially may play an important role in the development and growth of AS. A lack of vitamins B6, B12, and folic acid can result in hyperhomocycteine. Therefore, we speculated that the hyperhomocycteine might also, in turn, interfere with the level of methylation in the MTHFR gene promoter region and affect the expression of mRNA. However, whether the interference is the cause of DNA hypermethylation or hypomethylation has not yet to be reported. The modification of these two different ways also represents two different pathophysiologies which must be determined by further study.

The key enzyme in the Hcy metabolism process is MTHFR, and the MTHFR gene $677 \mathrm{C} / \mathrm{T}$ mutation is common and can produce variations based on Hinf I restriction enzyme digestion sites. Hence, the heat sensitivity of MTHFR results in changes in the activity of decline and improves the level of plasma Hcy. ${ }^{[13]}$ The MTHFR gene polymorphism and folic acid metabolism can be damaged, leading to increased concentrations of plasma Hcy. Our study observed that the plasma Hcy level of the T/T genotype was significantly higher than that of the $\mathrm{C} / \mathrm{T}$ or $\mathrm{C} / \mathrm{C}$ genotype in AS. The results showed that the $\mathrm{T} / \mathrm{T}$ genotype is closely related to increased plasma Hcy concentration. It is worth noting that the T/T genotype in the AS group was significantly higher than those in the controls, but it can not be stated for certain that the MTHFR T/T genotype is a susceptibile gene to AS. This hypothesis would need to be studied further.

The relationship between the gene polymorphism of MTHFR C677T and rheumatic diseases has recently been researched. Koubaa et al. ${ }^{[14]}$ in their study results showed that the ratio of $\mathrm{T} / \mathrm{T}$ genotype in $\mathrm{BD}$ patients compared with the control group was significantly different, and this was related to higher concentrations of plasma Hcy. Marasini et al. ${ }^{[6]}$ did not support the point that the MTHFR C677T gene mutation increases the susceptibility of patients to systemic sclerosis, and at present, there are very few study reports about the gene polymorphism of MTHFR C677T with AS. Our research showed that there was no difference between the frequency distribution of the MTHFR genotype $\mathrm{C} / \mathrm{C}$ and the $\mathrm{C} / \mathrm{T}$ gene in the $\mathrm{AS}$ group and the control group, but the ratio of the $\mathrm{T} / \mathrm{T}$ genotype mutation was different in the AS and the controls. In the treatment of cancer and rheumatic diseases, the polymorphism of MTHFR C677T can increase the incidence of methotrexate toxicity, but folic acid supplements can reduce the toxicity of methotrexate and do not affect the treatment. ${ }^{[15,16]}$ This prompted us to hypothesize that certain nutritional factors may be related to the incidence and treatment of AS. It is likely that a complicated process related to the control of gene cytokines and other factors has led to the incidence of AS, but the specific mechanisms still need further study.

In short, our research showed that plasma Hcy concentration in AS patients was significantly higher than normal. The MTHFR gene T/T mutation is an important mechanism which has an impact on hyperhomocysteine, and this mutation may be related to the occurrence of AS.

\section{Acknowledgements}

We here by express our thanks to a Major Project Grant of Frontiers in Sciences, Central South University (Ministry of Education of China). 


\section{Declaration of conflicting interests}

The authors declared no conflicts of interest with respect to the authorship and/or publication of this article.

\section{Funding}

The authors declared that this work was supported by a major project grant from Frontiers in Sciences, Central South University (Ministry of Education of China).

\section{REFERENCES}

1. Lazzerini PE, Capecchi PL, Selvi E, Lorenzini S, Bisogno S, Galeazzi M, et al. Hyperhomocysteinemia, inflammation and autoimmunity. Autoimmun Rev 2007;6:503-9.

2. Liu CC, Ou TT, Wu CC, Li RN, Lin YC, Lin CH, et al. Global DNA methylation, DNMT1, and MBD2 in patients with systemic lupus erythematosus. Lupus 2011;20:131-6.

3. David R, Mellissa M. Epigenetics and human disease: translating basic biology 11 into clinical applications. CMAJ, 2006;1:341-8.

4. Vayá A, Santaolaria M, Micó L, Calvo J, Oropesa R, Villa P, et al. Thrombotic events in systemic lupus erythematosus. Its association with acquired and inherited thrombophilic defects. Clin Hemorheol Microcirc 2008;40:79-87.

5. Kartal Durmazlar SP, Akgul A, Eskioglu F. Homocysteine may involve in the pathogenesis of Behcet's disease by inducing inflammation. Mediators Inflamm 2008;2008:407972.

6. Kutilek S, Nemec V, Bockayova E. Elevated serum homocysteine levels in paediatric patients with primary Raynaud's phenomenon. Rev Bras Reumatol 2012;52:12830. [Abstract]

7. Xu XY, Zhou WH, Xiao CS, Li XF, Wang LY. A clinical study of hyperhomocysteinemia in rheumatological diseases. Zhonghua Nei Ke Za Zhi 2005;44:111-4. [Abstract]

8. Başkan BM, Sivas F, Aktekin LA, Doğan YP, Ozoran $\mathrm{K}$, Bodur H. Serum homocysteine level in patients with ankylosing spondylitis. Rheumatol Int 2009;29:1435-9.
9. Gonzalez-Lopez L, Sanchez-Hernandez JD, AguilarChavez EA, Cota-Sanchez AR, Lopez-Olivo MA, VillaManzano AI, et al. Hyperhomocysteinemia in ankylosing spondylitis: prevalence and association with clinical variables. Rheumatol Int 2008;28:1223-8.

10. Capkin E, Karkucak M, Akyüz A, Alver A, Turkyilmaz AK, Zengin $\mathrm{E}$. The relationship between plasma homocysteine level and different treatment modalities in patients with ankylosing spondylitis. Rheumatol Int 2011. [Epub ahead of print]

11. Wei JC, Jan MS, Yu CT, Huang YC, Yang CC, Tsou HK, et al. Plasma homocysteine status in patients with ankylosing spondylitis. Clin Rheumatol 2007;26:739-42.

12. Schroecksnadel K, Frick B, Wirleitner B, Winkler C, Schennach H, Fuchs D. Moderate hyperhomocysteinemia and immune activation. Curr Pharm Biotechnol 2004;5:107-18.

13. Holm PI, Hustad S, Ueland PM, Vollset SE, Grotmol T, Schneede J. Modulation of the homocysteine-betaine relationship by methylenetetrahydrofolate reductase 677 C->t genotypes and B-vitamin status in a largescale epidemiological study. J Clin Endocrinol Metab 2007;92:1535-41.

14. Koubaa N, Hammami S, Nakbi A, Ben Hamda K, Mahjoub $\mathrm{S}$, Kosaka $\mathrm{T}$, et al. Relationship between thiolactonase activity and hyperhomocysteinemia according to MTHFR gene polymorphism in Tunisian Behçet's disease patients. Clin Chem Lab Med 2008;46:187-92.

15. Speletas M, Papadopoulos N, Daiou C, Katodritou E, Pavlitou-Tsiontsi A, Galanopoulou V. Relationship between 5,10-methylenetetrahydrofolate reductase C677T gene polymorphism and methotrexate related toxicity in patients with autoimmune diseases receiving folic acid supplementation. Ann Rheum Dis 2005;64:1791-2.

16. Ranganathan P, Culverhouse R, Marsh S, Mody A, ScottHorton TJ, Brasington R, et al. Methotrexate (MTX) pathway gene polymorphisms and their effects on MTX toxicity in Caucasian and African American patients with rheumatoid arthritis. J Rheumatol 2008;35:572-9. 